SAD / JSR

Sosyoloji Araştırmaları Dergisi / Journal of Sociological Research

Cilt / Volume 22 Sayı / Number 1 (Nisan / April 2019) : (278-303)
Araştırma Makelesi / Research Article

Geliş Tarihi / Submited: 01.03.2018

Kabul Tarihi / Accepted: 18.10.2018

\title{
UZUN YOL ŞOFÖRLERİ HAKKINDA BİR SAHA ARAŞTIRMASI
}

Onur $\mathrm{UCA}^{1}$

ÖZ

Bu araştırma Türkiye'de çalışan uzun yol şoförleri hakkındadır. Araştırmada nitel araştırma yöntemi kullanılmıştır ve şoförlerle derinlemesine görüşmeler gerçekleştirilmiştir. Araştırma sonucunda belirli verilere ulaşılmıştır. Uzun yol şoförlerinin ilişki ağı çıkartılmış; hız, korku, umut, yemek, uzak konularına dair fikirleri öğrenilmiş ve yaşadıkları sorunlar ve önerileri tespit edilmiştir. Sonuç bölümünde ise uzun yol şoförlerinin yaşamlarında ortaklaşan yönler aktarılmıştır.

Anahtar Kelimeler: Uzun Yol Şoförleri, Nitel Araştırma Yöntemi, Sanı Yaşamlar.

${ }^{1}$ Arş. Gör. Dr., Mersin Üniversitesi Fen Edebiyat Fakültesi, Sosyoloji Bölümü 


\title{
A FIELD STUDY ON LONG DISTANCE TRUCK DRIVERS
}

\begin{abstract}
This research is carried out through qualitative research method in the case of long distance drivers with whom in-depth interviews were conducted in Turkey. Specific data has been obtained as a result. The network of long distance drivers has been outlined,their ideas about speed, fear, hope, food and distance have been revealed, the problems they generally face and their suggestions have been ascertained. The shared aspects of their lives have been indicated in conclusion.
\end{abstract}

Key Words: Long Distance Drivers, Qualitative Research Method, Assumption Life. 


\section{GİRIŞ}

Yük taşımacılığ1 yapan uzun yol şoförleri, üretim ilişkisi içerisinde üretim, mübadele, tüketim döngüsündeki metaların fiziksel olarak mekanlar arasındaki dolaşımını karadan sağlayan kişilerdir. Çalışma uzun yol şoförlerinin yaşamları hakkında sosyoloji biliminin araştırma tekniklerini kullanarak elde edilen verilerin bilimsel analizini gerçekleştirmeyi hedeflemiştir.Uzun yol şoförlerinin çalışma koşullarını, yaşama dair görüşlerini, beklentilerini, sorunlarını ve önerilerini analiz eden bilimsel araştırma az sayıdadır. $\mathrm{Bu}$ bağlamda araştırma çalışma yaşamında yer alan uzun yol şoförleri hakkında enformellik olgusuna odaklanan bir olgubilim (fenomenoloji) çalışması olarak tasarlanmıştır. Olgubilim deseni farkında olduğumuz ancak derinlemesine ve ayrıntılı bir anlayışa sahip olmadığımız olgulara odaklanmaktadır. Bir başka ifade ile bize tümüyle yabancı olmayan aynı zamanda da tam anlamını kavrayamadığımız olguları araştırmayı amaçlayan çalışmalar için olgubilim uygun bir araştırma zemini oluşturmaktadır (Yıldırım ve Şimşek: 2013:75).

Olgubilimsel araştırmalarda ele alınan fenomen hakkında derinlemesine bilgi edinilmesi hedeflenmektedir. Derinlemesine bilgiyi elde etmek için en çok kullanılan araştırma tekniği görüşmedir. Görüşmeler derinlemesine görüşme şeklinde gerçekleştirilmekte ve uzun süreler içinde yapılmaktadır (Yıldırım ve Şimşek, 2013). Araştırma konusu hakkında farklı açılardan bilgi edinmek, yaşam pratiklerinin içine girebilmek ve fenomenin içinde olduğu bağlamı anlayabilmek için derinlemesine görüşmelere en verimli yoldur.

Olgubilimsel araştırma neticesinde gerçekleştirilen görüşmelerden elde edilen verilerin analizinde son dönem Fransız sosyoloji literatürünün iki önemli ismi olan Pierre Bourdieu ve Luc Boltanski’den yararlanıld1. Araştırma literatürünün birinci ismi olan Pierre Bourdieu oluşturduğu bakış açısı ve geliştirdiği kavramlar ile sosyoloji literatüründe önemli bir isimdir. Bourdieu rasyonel eylem kuramlarına karş1 insanların pratiklere, kültürel yatkınlıklara, eğilimlere, bedensel alışkanlıklara göre hareket ettiğini bilimsel 
olarak göstermesi bakımından sosyoloji literatüründe bir mihenk taşı olarak kabul edilmektedir. Kuramında alandan çıkarttığı ve kuramı içerisinde özgün anlamlara sahip olan belirli bir kavramlar dizisi bulunmaktadır. Bu kavramların başında sosyolojinin inceleme konusu olan olguların gerçekleştiği yer olarak “alan” kavramı gelmektedir. Alan bireyler arası mücadelenin yaşandığı mekandır. Mücadeleye giren bireyler ise belli kuşanmışlıklar ile alana dâhil olmaktadır. Bu kuşanmışlıklar ise "sermaye" olarak adlandırılmaktadır (Bourdieu ve Wacquant, 2003). Alanın geniş tabanlı mücadele olanaklılı̆̆g nedeniyle sermayenin yapısı yekpare değildir. Bu nedenle sermaye birbiri ile ilişkili olan dört ayrı alttüre ayrılmıştır. Bunlar ekonomik, kültürel, sosyal ve simgesel sermaye tipi olarak adlandırılmaktadır. Sermayeler arasında geçişlilik bulunmaktadır. Sermayelerin her biri alanda kendi içerisinde dengelerin ve çatışmaların gerçekleştiği yerlerdir. Ekonomik sermaye, ekonomik kaynakların ve yaptırım olanaklarının elinde bulundurulmasını belirtmektedir. Sermaye mülkiyeti ve geliri elinde bulundurma durumu temel ekonomik sermaye öğeleridir. Ancak Bourdieu ekonomik indirgemeci değildir. Çünkü ekonomik ve ekonomik olmayan ayrımını reddederek alanın pratiklerini çalışmıştır (Göker, 2007). Kültürel sermaye ise entelektüel birikim ile ilişkilidir. Kültürel sermayenin üç alt biçimi vardır. İlki çocukluktan başlayarak ailenin içinde bulunduğu sosyal konumla belirlenen, sosyal kültürel alışkanlıkların belirlenmesini sağlayan bedenleşmiş kültürel sermayedir. İkincisi kitap, resim, sanat eseri yaratma gibi konularda kişinin hünerlerini belirleyen nesneleşmiş kültürel sermayedir. Üçüncüsü ise eğitimle elde edilmiş ve onaylanmış kurumsallaşmış kültürel sermayedir (Göker, 2007: 282-283). Sosyal sermaye, bireyin diğerleri ile kurduğu ilişkiler bütünü içerisinde bireyin yükümlülükleri, ayrıcalıkları ve itimatları gibi olgular tarafından oluşturulan sermayedir. Son sermaye tipiyse simgesel sermaye tipidir. Simgesel sermaye ayrı bir sermaye tipi değildir. Ekonomik, kültürel ve sosyal sermaye tiplerini belli oranda içinde barındırarak alanda söz sahibi olmak için geçerli sermayeye dönüşmesini anlatmaktadır (Göker, 2007). Uzun yol şoförlerine dair yapılan bu araştırmada verilerin analizi için Bourdieu'nun diğer kavramları paranteze alınarak ekonomik, sosyal, kültürel ve simgesel sermaye kavramları kullanıldı. Böylece şoförlerin kültürel, sosyal ve ekonomik sermayelerini, bu 
sermayeler arasındaki ilişkileri ve çalışma yaşamında bulunan diğer insanların sermaye biçimleri ile uzun yol şoförlerinin sermaye biçimlerindeki farklılıklar, benzerlikler ve bunların yaşamlarını nasıl etkilediği araştırıldi.

Araştırma literatürünün ikinci temel ismi ise Luc Boltanski' dir. Abisi Pierre Bourdieu'nun arkadaşı olan ve Bourdieu'nun araştırma ekibinde yer alan, uzun dönem Bourdieu ile birlikte çalışmış olan Boltanski'nin değer ekonomileri anlayışı ve değer ekonomilerinin işleyiş mekanizması araştırmanın sonuç bölümünde elde edilen verileri analiz etmek için kullanılan ikinci temel literatür olarak belirlenmiştir. Boltanski, Laurent Thêvenot ile yazdığı "Gerekçelendirme Üzerine Değerin Ekonomileri” (Boltanski ve Thévenot, 2006) adlı eserde insanların konumlarını nasıl meşrulaştırdığı ve gerekçelendirdiği konusu üzerinde durmaktadır. Boltanski konuyu insanların değerleri arasındaki ilişkiler üzerinden açıklamıştır. Altı dünya belirlemiş ve dünyalar arasındaki ilişkiyi ortaya koyarak gerekçelendirmeler üzerinden bir değerler ekonomisi inşa etmiştir. Bu dünyalar; Esinlenme dünyası; bireysel yaratıcılık ve orijinalliğe dayanır. Değer, bireyin yaratıcılık kabiliyetiyle ilgilidir. Ailesel dünya; bireyin ailesinden getirdiği nesil ayrımı, gelenek ve hiyerarşi önemlidir. Toplumda buradan gelen bilgilerin mantığına başvurularak hareket edilir. Yurttaşlık dünyası; kendi değer ve ilgilerini bir kenara bırakan birey "ortak iyiye” doğru hareket eder. Ortak iyiyi belirleyen yasalar, haklar, refah devleti içerisinde yer alan dayanışma ve saygı prensipleridir. Endüstriyel dünya; teknik ve bilimsel prensiplere göre belirlenir. Değeri işlevsellik, üretkenlik ve verimlilik üzerinden oluşturulur. Piyasa dünyası; adından da anlaşıldığı gibi ekonomi dünyasıyla ilgilidir; ancak sadece sistemsel bir ekonomiye indirgenemez, bireylerin meta alış ve satış ilişkilerini de içerir. Bireyler arasındaki meta yarışına dayanır. Bireyler zengin olduğu için değerlidir. Şöhret dünyası; değerin insanların aklında ve fikirlerinde oluşturulamazsa hiçbir şey olduğu fikrine dayanmaktadır. İnsan değerinin ölçülebilirliği kamusal değer içerisindeki geleneksel işaretlere bağlıdır. Başarı üne ve toplum içerisinde görünür olmaya bağlıdır (Boltanski ve Thévenot, 2006:159-211).

SAD / JSR

Cilt / Volume 22 Sayı / Number 1 
Değerler dünyasının işleyişine göre insanlar aynı anda birden fazla dünya içinde hareket ederek eylemlerini gerekçelendirebilmektedir. Ancak dünyaların etkisi her insanda aynı düzeyde değildir. Hangi dünyanın öne çıkarılacağının belirlenmesi gerekçelendirme gücüyle ilişkilidir. Benzer dünyalara sahip insanlar birbirlerinin gerekçelendirmelerini ve stratejilerini daha kolay anlamaktadır. Farklı dünyalardan gelen insanlar için birleştirici unsur ise “ortak iyi” üzerinde uzlaşılmasıdır. Bu “ortak iyi” farklı dünyalardan gelen insanların kesiştiği çıkarı ifade etmektedir. Genel geçer bir ortak iyi yoktur. Kişilerin ve ilişkilendikleri yapının biçimi ortak iyiyi belirler. Gerekçelendirme dünyalarına kişiler arası ilişkilerin çıkara ve çatışmaya dayanmadığ barış durumlarında ve ikili ilişkilerde gücün kuralsız kullanıldığg savaş durumlarında ihtiyaç duyulmaz. Bu rejimler hem denkliğin hem de tartışmanın olduğu anlarla ilişkilidir (Jacquemain, 2008). Uzun yol şoförlerinin konumlarını, eylemlerini nasıl meşrulaştırdıklarını anlamak için Boltanski’nin değer dünyaları kullanılmıştır. Uzun yol şoförlerinin hangi değer dünyalarında güçlü oldukları, hangi değer dünyalarını öne çıkarttıkları ve diğer çalışanlardan farklılaştıkları Boltanski'nin değer dünyalarının ekonomisi anlayışı üzerinden analiz edildi.

\section{YÖNTEM}

Olgubilim araştırmalarında başlıca veri toplama aracı görüşmedir. Olgulara ilişkin yaşantıları ve anlamları ortaya çıkarmak için görüşmenin araştırmacılara sunduğu etkileşim, esneklik ve sondalar yoluyla irdeleme özelliklerinin kullanılması gerekmektedir (Yıldırım ve Şimşek, 2013:80). Bu nedenle alan araştırmasında derinlemesine mülakat tekniği kullanılarak veriler elde edilmiştir. Görüşmeler Mersin, Adana, Niğde ve Nevşehir il sınırlarında, illeri birbirine bağlayan yollarda gerçekleştirilmiştir.Alan araştırması süresince yük taşımacılığ1 yapan 15 şoför ile görüşülmüştür. Bu şoförlerin 8 tanesi kendi aracına sahiptir. 7 tanesi ise şoför olarak şirket veya şahıs arabasında çalışmaktadır. Ayrıca uzun yol şoförü olarak şahıs, şirket veya kendi arabasında çalışmakta olup gündelik yaşamına dair videolar hazırlayarak youtube kanalına yükleyen 
ve on binlerce takipçisi olan kişilerin ${ }^{2}$ anlatımlarından ve gösterdikleri yaşamlarından da oldukça yararlanılmıştır. Görüşmeler yarım saat ile iki saat arasında değişen sürelerde tamamlanmıştır. Görüşülen uzun yol şoförlerinin yaşları 32 ile 56 arasında değişiklik göstermektedir. Aylık kazançları ise iki bin ile beş bin tl arasında değişmektedir. Alan araştırmasında görüşmecilerin sayısının belirlenmesi, verimli ${ }^{3}$ görüşmelerde kişilere yöneltilen sorulardan alınan cevapların benzerlik kazanmasına bağlıdır. Elbette görüşmede görüşülen kişilerden elde edilecek bilgiler bitmemektedir. Biten şey, araştırmacının kafasındaki konuya dair belirlediği cevapsız sorulardır (Hammersley ve Atkinson, 2007:91-92). Bu aşamada iki seçenek vardır. İlki yanıtlar yeterli değil ise yeni sorular eklenmeli ve yeni görüşmelere başlanmalıdır. Yanıtlar yeterli ise alan araştırması tamamlandı denilebilmelidir. Soruların yanıtları derlendiğinde bir fenomen olarak uzun yol şoförleri hakkında çalışma için gerekli verilerin elde edildiği anlaşılmış ve alan araştırması tamamlandi denilmiştir.

Nitel araştırmalarda en önemli öğelerden birisi güven duyulabilirlik kriterlerine uyulup uyulmadığının saptanmasıdır. Nitel araştırmada elde edilen verilerin geçerliliği ve güvenirliği inanılabilirlik, güvenilebilirlik, onaylanabilirlik ve aktarılabilirlik kriterleri üzerinden saptanmaktadır (Başkale, 2016). İnanılabilirlik, görüşmeciler ile uzun soluklu görüşme, diğer görüşmeci teyidi ve araştırmacının önyargısızlığı üzerinden belirlenmektedir. Güvenilirlik ise benzer araştırmanın sonuçlarının incelenmesi ve literatürün araştırılması ile belirlenmektedir. Onaylanabilirlik, objektiflik ve önyargısız verilerin sunulması, aktarılabilirlik ise benzer çalışmalara bilginin aktarılabilmesi ile ilişkilidir (Başkale, 2016). Bu dört kriterin sağlanması nitel araştırmanın güvenli ve geçerli olduğunu belirlemektedir. Bu nedenle araştırma süresince araştırmacı önyargısız bir şekilde davranma hususunda duyarlı davranmıştır. Bir görüşmeden elde edilen

${ }^{2}$ Yaş sırasına göre; Aydın Bahar, Ümit Can,Hüseyin Gülseven, Çağlar Çalışkan, Fatih Karanfil, Enver Tuna, Nizamettin Akbaş,Muhammet Atar, Nazım Zeki Uysal.

${ }^{3}$ Verimli görüşme, zaman süresi, görüşmecinin yanıtlara cevap verme isteği, görüşme koşulları nedeniyle görüşmenin yarıda kalması, görüşmecinin görüşlerinin derinlemesine mülakat için yeterli bilgi içermemesi veya her soruya yanıt vermek istememiş olması gibi etkenler üzerinden belirlenmiştir.

SAD / JSR

Cilt / Volume 22 Sayı / Number 1 
veriler diğer görüşmelerde görüşmecilere teyit ettirilmiştir. Araştırmada elde edilen verilerin literatür ile uygun olmasına özen gösterilmiştir.

Görüşmeler esnasında farklı sorularından oluşan iki farklı yapılandırılmış soru formu kullanılmıştır. İlk form şoförlerin şoförlük mesleğini yaparken kurdukları ilişki yapısını öğrenmeye yönelik sorulardan oluşmaktadır. İkinci form şoförlerin trafiğe, yaşamlarına, küçük araç sürücülerine, korku, umut, yemek, hız, sorun, umut anlayışlarına yönelik sorulardan oluşmaktadır. İlk formdan elde edilen veriler bulgular başlığ 1 altında "uzun yol şoförü olma ve sürdürme şartları" alt başlığı içerisinde analiz edilmiştir. İkinci formdan elde edilen veriler ise bulgular kısmında yer alan "uzun yol şoförlerinin hız, korku, umut, uzak ve yemek anlayışları" ve "uzun yol şoförlerine bakış açısından sorunlar ve öneriler" alt başlıkları içerisinde incelenmiştir.

\section{BULGULAR}

\subsection{Uzun Yol Şoförü Olma ve Sürdürme Şartları}

Bir şoförün bu işi meslek olarak yapması için gerekli ilk şey araç sürme ehliyetidir. Ehliyet alma yaşı tır ve kamyon için (C, CE, D1 ve D1E sınıfı belgeler) 21, otobüs için ise (D, DE sınıfı belgeler) 24 olarak saptanmıştır (Karayolları Trafik Yönetmeliğinde Değişiklik [KTYD], 2015). Ehliyet aracı sürme için yetki sağlamasına karşın şoförlükten para kazanmak için yeterli değildir. Şoförlüğü meslek olarak yapabilmeniz için yapacağınız ticari işin mahiyetine göre uygun SRC belgesi almanız gerekmektedir. SRC “sürücü” kelimesinde yer alan ünsüz harflerin bileşiminden oluşmaktadır. Yük veya yolcu taşımacılığı ile kullanılacak aracın yapısına göre beş (5) adet SRC türü bulunmaktadır. Ehliyet almaya hak kazanmış her şoför bu belgeyi alma hakkına sahiptir. Yalnızca büyük otobüs kullanacak şoförler özel alt yaş uygulamas1 bulunmaktadır. Büyük otobüs kullanmak için en az 26 yaşından gün almak gerekmektedir. Ayrıca 66 yaşından gün almış şoförler SRC belgesi almak için başvuru yapamaz (Uslu, 2017). Ticari uzun yol şoförü olmak için gerekli olan son belge ise psikoteknik belgesidir. Bu belge şoföre sağlık bakanlığı tarafindan belirlenen yetkili kurumlarca psikoteknik değerlendirme yapılması sonucu verilmektedir. Psikoteknik 
değerlendirme bireyin belirli bir işteki yeterliliğinin ortaya konması amacıyla gerekli bedensel ve zihinsel özelliklerinin testler aracılığıyla ölçülmesi, bireyin belirli bir işe uygun olup olmadığını anlamaya yönelik tasarlanmış inceleme ve değerlendirme yöntemidir (Demiryolu Eğitim ve Sınav Merkezi Yönetmeliği [DESY], 2016 ve Karayolu Taşıma Yönetmeliğinde Değişiklik [KTYD], 2009). Ehliyet, SRC ve psikoteknik belgelerini tamamlayan sürücü başkasına ait araçta çalışarak gelir elde etmeye başlayabilecek yetkinliği elde etmiş bulunmaktadır. Ancak kendi aracını alarak kendi işini yapmak ister ise karayolları taşıma yönetmeliğine göre daha farklı yetki belgelerine sahip olmak zorundadır. Bu belgelerin bir kaçı özetle, B1 belgesi; otobüsle uluslararası ve şehirlerarası tarifeli yolcu taşımacılığı, C1 belgesi;kendi iştigali ile ilgili uluslararası ve yurtiçi eşya taşımacılığı, K1 belgesi; yurtiçi ticari eşya taşımacılığı belgesidir.

Bu belgelerle birlikte yük taşımacılığı yapan şoförleri ikiye ayırmak gerekmektedir. Ayrım, kendi aracına sahip, mal sahibi olarak çalışan şoförler ve başka şahıs veya şirkete ait aracı aylık, haftalık veya sefer başı ücret karşı1ığı kullanan şoförler arasındadır. Ayrımın ortaya konması şoförlerin çalışma ilişkilerini anlamak için önemlidir. Ayrım, şoförlerin hayatlarında var olan sorumluluklarını ve sorumlu oldukları kişilerin konumunu değiştirmektedir. Kendi aracına sahip olan şoförler aracın bakımı, kaskosu, trafik vergisi, yakıt sarfiyatı, kullanım biçimi, yük seçimi, sefer planı, taşıma ücreti gibi konularda söz hakkına sahiptir. Başka bir şahsın veya şirketin aracını kullanan şoförler ise bu konularda söz hakkına sahip değildir. Şirketin veya araç sahibinin direktifleri doğrultusunda iletişim içinde hareket etmektedirler. Kendi aracına sahip şoförler; yük tedarikçileri (komisyoncular), diğer araç sahibi şoförler, firma yetkilileri (aracını firmaya kayıt ettirdiyse) ile uyumlu çalışmak zorundadır. Sadece şoför ise firma yetkilisi, araç sahibi veya araca sahip olan şirketin çalışanlarıyla uyumlu çalışmalıdır. Özetle şoför; şirket çalışanları, yöneticileri, komisyoncular, diğer şoförler ile koordineli çalışmak zorundadır. Hiçbir şoför yolda göründüğü gibi tek başına değildir. Üstüne yüklenen birçok sorumluluk bulunmaktadır. Bu ayrımları daha iyi anlayabilmek için aşağıdaki tabloya bakalım.

SAD / JSR

Cilt / Volume 22 Sayı / Number 1 


\section{Tablo 1. Şoför İlișkileri Tablosu}

\begin{tabular}{|l|l|}
\hline Şoför İlişkileri Tablosu & $\begin{array}{l}\text { Varlığını Devam Ettirmek İçin Zorunlu Olarak } \\
\text { Bağlı Bulunduğu Konumlar ve Kişiler }\end{array}$ \\
\hline \multirow{3}{*}{ Araç Sahibi Olarak Şoför } & $\begin{array}{l}\text { Komisyoncu } \\
\text { Firma kuralları }{ }^{4} \\
\text { Kendi gibi araç sahibi diğer şoförler (komisyon } \\
\text { vermeden veya daha az komisyonla iş bulabilmek } \\
\text { için) }\end{array}$ \\
\hline Sadece Şoför & $\begin{array}{l}\text { Firma Yetkilisi } \\
\text { Araç sahibi }\end{array}$ \\
\hline
\end{tabular}

Tablodan görüldüğü üzere araç sahibi olarak şoför ile sadece şoför arasında çalışma koşulları bağlamında zamansal ve mekânsal olarak bir fark olmamasına karşın bağlı bulunduğu kişiler ve konumlar birbirinden farklıdır.

Anlaşılmaktadır ki, şoför varlığını sürdürmek için belirli ilişki biçimlerini sürdürmek zorundadır. Mülkiyet şoförün varlığını sürdürmek için bağımlı olduğu ilişkilerin yapısını değiştirmektedir. “Özel mülk sosyal düzenlemeyi sağlayan bir sistem olarak kendi eylem alanımızın sınırlarını ve birinin diğeri üzerindeki imtiyazının kabulünü yansıtmaktadır” (Shaffer, 2009: 189). Mülk sahibi olan şoför seçme, planlama, düzenleme ve zamanını belirleme hakkına sahiptir. Sadece şoför olan kişi bu hakların araç sahibine ve aracın çalıştı̆g firmanın kurallarına devretmiştir.

${ }^{4}$ Yalnızca aracını bir firma altında çalıştırıyorsa firmanın kurallarına bağlıdır. 


\subsection{Uzun Yol Şoförlerinin Hız, Korku, Umut, Uzak ve Yemek Anlayışları}

Bir önceki bölümde şoförlerin iş ilişkilerine dair temel işleyiş bilgileri aktarıldı. Bu bölümde ise alan araştırmasında "genel sorular" adı altında sorulan sorulardan elde edilen verilerin yorumlanması yapilacaktır.

Türkiye' de kazaya bağlı ölümlerin başında trafik kazasından kaynaklanan ölümler gelmektedir. 2016 yılı verilerine göre 7300 kişi trafik kazasından dolayı hayatını kaybetmiştir (TÜİK, 2017). Bu kazalara neden olan en önemli faktör ise insan kusuru olarak saptanmıştır (Öztürk, 2013: 48). İnsan kusurunun başında ise aşırı hız ve yorgunluk önemli bir yer tutmaktadır. Aşırı hız ve yorgunluğun engellenmesine yönelik denetleme çalışmaları ağır vasıtalarda takograf ${ }^{5}$ cihazı ile yapılmaktadır. Kazaların başlıca sebebi olan aşırı hız ve yorgunluk olması nedeniyle her zaman yollarda olan çoğu zaman araçlarının teneke kupasında ${ }^{6}$ yaşam mücadelesi veren şoförlere hızın ne olduğunu, "hız yapmak zorunda kalıp, kalmadıklarını ve gerektiğinde hız yapmazsanız işini kaybetme şansınız var mı?” diye soruldu. Alınan verilere göre araç sahibi şoförler hız konusunda daha hassas davranmaktadır. Görüşmeler sırasında bir uzun yol şoförü yanımızdan hızla geçen bir tırın arkasından bakıp "bu aracı süren kesin arabanın sahibi değil, araba onun olsa böyle hız yapıp arabasını yormaz, tehlikeye atmaz” demiştir. Hız konusunda dikkatli diğer kesim ise şahıs arabasının şoförleridir.

"Biz Boğazyılan Nakliyeciler Kooperatifi olarak hız kurallarına uyarız. Ben uykum gelirse uyurum. Arabanın sahibi de neden uyudun demez. Bak buraya ben gece geldim 23:00 gibi uyudum. 11 saat

\footnotetext{
${ }^{5}$ Takograf, sürücülerin trafik denetimlerinde ayrıntılı olarak kontrol edilebilmeleri için, aracın hızını, aracın kullanım sürelerini, sürücünün dinlenme süreleri gibi bilgileri, aracı kullanan sürücünün kimlik bilgileriyle birlikte hafizasında saklayan, istenildiğinde takografın göstergesinden ya da mini yazıcısından, rapor veya grafik olarak çıktı vererek, kullanıcısını bilgilendiren bir cihazdır (E Taşımacılık).

${ }^{6}$ Ağır vasıtalarda dorsenin veya kasanın önündeki kabini de içeren bölüme kupa adı verilmektedir.
} 
olmuş halen sıra bekliyorum (Erkek, 56 yaşında, emekli ve çalışmaya devam ediyor, sadece şoför, 2400 TL, Yozgat).

Türkiye' de hız konusunda takograf cihazının hız ve zaman dilimlerine uymadan hareket eden şoförler ise genellikle firma şoförleri olarak karşımıza çıkmaktadır. Firmalar belli zamanlarda müşteri memnuniyeti, belli zamanlarda daha fazla iş alabilmek için şoförden daha hızlı gelmesini talep edebilmektedir. Özellikle hale sebze meyve taşıyan (taşımacılık sektöründe "jete kalkmak" diye anılmaktadırlar) araçlar meyve sebzenin taze kalması ve sabah haline yetişmesi için hız sınırlarını aşarak hareket etmektedir. Bu şoförlerin bazısı takograf cihazlarında farklı hilelere başvurarak cihaz düzgün çalışıyormuş gibi göstermektedir.

"Belli bir hızın altında gidersen firman bir kere, iki kere bakar hep geç kalıyorsan senle çok çalışmak istemez. Hızla gel der. Ama Avrupa'da daha farklı. Kurallar çok katı. Mesela hafta sonu tır parkında tırın içinde değil otelde yatmak zorundasın. Cezası var. Bizim firmalar tırda yat, ceza gelmezse kar gözüyle bakıyor (Erkek, Yaş 54, 14 yıldır uluslararası şoförlük yapıyor, 5000 TL, Nevşehir).

Şoförlere bir diğer soru olarak "Türkiye'de trafiğin en büyük sorunu nedir?" ve "Küçük araçlardan beklentiniz nedir?" sorusu yöneltildi. Ağız birliği etmişçesine şoförler Türkiye'de trafiğin en büyük sorunu olarak “saygısızlık”, “tahammülsüzlük”, "sabırsılılı” ve “anlayışsızlık” cevaplarını vermişlerdir.

“Şimdi 20-25 ton yük taşıyorum. Araçla 35-40 ton, rampa çıkıyorum. Önümdeki aracı geçmem gerek yoksa vites düşecek mazot (harcama) artacak, zaman artacak, arkamda 1 ton araç yol vermemek için hızlanıyor selektör de selektör. Az bir bekle zaten altındaki araba hafif ben geçeyim sen yine hızlanır gidersin. (Erkek, 35 yaşında, 9 yıldır yurtiçi şoförlük yapıyor, 2000 TL, Niğde)"

Şoförler gereksiz selektör kullanımından oldukça rahatsız olmaktadır. Ayrıca trafikteki "saygısızlığı” kendi yöntemleriyle aşmaya çalışan şoförler bulunmaktadır. 
“Önümdeki aracı geçtiğim belli olmasın diye sinyal vermiyorum. Neden? Çünkü ben sinyal verince arkadan gelen taksi yavaşlayıp yol vermek yerine aman bu geçmeden geçeyim diyor. Daha da gaza basıyor.(Erkek, 48 yaşında, 15 yıldır sadece şoförlük yapıyor, 1600-2500 arası, Nevşehir) "

Şoförlerin küçük arabalardan beklentileri ise "anlayış" olarak karşımıza çıkmaktadır. Aracı kullanırken birçok yeri (özellikle sağ alt taraf) göremediklerini, aniden duramayacaklarını, manevra yaparken bıraktıkları boşluklara firsatçı küçük araç sürücülerinin doldurmasından, sağlayarak önlerine geçmelerinden, rampada bilerek frene bastırtmalarından oldukça şikâyetçidirler.

Şoförler için “Uzak neresidir? Aile yaşamınız nasıldır?”Diye sorulduğunda, uzaklık anlayışlarının olmadığı görülmüş̧ür. Aile yaşamlarında ise alışılmış bir hasretlik hâkimdir. Özellikle son dönemde sosyal medyanın, iletişim teknolojilerinin ve görüntülü konuşmanın gelişmesi ile hasretlik anlayışı değişmiştir. Ancak doğum, ölüm, düğün, bayram da aileleriyle beraber olamamak aile yaşamındaki hasretliğin en önemli göstergeleri olarak karşımıza çıkmaktadır.

"Üç tane çocuğum var nasıl büyüdüler bilmem. Hanım büyüttü onları” (Erkek, 56 yaşında, emekli ve çalışmaya devam ediyor, sadece şoför, 2400 TL, Yozgat).

Şoförlere sorulan bir diğer soru ise, "yolda yemek alışkanlıklarınız nasıldır? Şunu hep yerim, yanımda hep şu vardır. dediğiniz bir şey var mı?” şeklinde olmuştur. Alınan yanıtlarda ortaklaşan öğelerin başında zorunlu kalmadıkça bilmedikleri yerde yemek yemedikleri görülmüştür. Arkadaş tavsiyesi ve daha önce kazanılan tecrübeler ile lokanta seçmektedirler. Varış yerine varış zamanı kısıtlı ise lokantalarda yemek yemeden araçta bulunan bisküvi, kek gibi atıştırmalıklarla idare etmektedirler. Ayrıca bazı şoförler eşlerinin hazırladığ 1 yolluklarla bir süre idare etmekte veya araçlarında küçük tüp taşımaktadır. Bu şoförler zaman ve mekân bulduklarında kendi yemeklerini kendileri yapmaktadır.

"Ben bilmediğim yerde yemek yemem. Eğer bilmediğim yerde yemek yiyeceksem yıkanması, yağı, tuzu, baharatı en az olan yemeği tercih ederim. Mesela kolay kolay ıspanak yemem. Nasıl yıkanmış, 
nasıl yağ var bilemem. Onun yerine tavuk ızgara yerim. En azından ne eti olduğu belli." (Erkek, 51 yaşında, 26 yıldır kendi aracında şoför, 3000-4000 TL arası, Kayseri)

Şoförler, "yolda en çok dinlendiğiniz müzik türü hangisidir?” sorusuna verdikleri yanıtı genç şoförler ve orta yaşlı şoförler olarak ayırarak anlaşılabilmektedir. Genç şoförler cep telefonu interneti ve usb belleklerden dinlenebilecek, güncel popüler müzikleri dinlerken orta yaşlı şoförler radyo dinleyerek haber ve hava durumu gibi bilgileri öğrenmeyi tercih etmektedir. Genelde müzik, radyo programları, haberler sessizliklerini paylaştıkları bir öğe olarak görülmektedir. En çok dinledikleri haberleri ve hava durumunu öğrendikleri radyo TRT Radyosu'dur. Bunun en önemli nedeni ise Anadolu'nun birçok yol güzergâhında TRT radyosunun yayın gücü olmasından kaynaklanmaktadır. Uluslararası tır şoförlüğü yapan bir şoför ise radyo kullanmasını şöyle açıklamıştır.

“Kendi müziklerim var onları dinlerim. Ama radyoyu dil öğrenmek için kullanırım. Mesela Macara (Macaristan) girdim. Açarım oranın bir radyosunu kulak aşinalığım olsunda Macar görevlilerle gümrükte, sınırda işlerimi çözerken anlayayım biraz.” (Erkek, Yaş 54, 14 yıldır uluslararası şoförlük yapıyor, $5000 \mathrm{TL}$, Nevşehir).

"Bu işi yaparken umudunuz, beklentiniz nedir? En çok korktuğunuz şey nedir?"sorusuna verilen yanıtlar birbirine benzer çıkmıştır. Hemen her şoförün bu işten beklentisi ve umudu emekli olmak olarak ortaya çıkmıştır. Ancak emekli olup halen bu işi yapan şoförlerde bulunmaktadır. Onların ise bu işte bir umutları yok. Emekli parası ile geçinemedikleri için ek gelir olarak eskisi kadar yoğun ve ağır işlerde çalışmak yerine daha rahat ve sakin yük ve yollarda çalışmayı tercih etmektedirler. Bu bağlamda emekli şoförlerin en büyük lüksü sağlık güvencelerinin olmasından dolayı iş seçme şanslarının, bir anlamda lükslerinin olmasıdır. Görüşülen şoförlerin hepsinin en büyük korkusu kaza yapmaktır. Özellikle ölümlü kazaya karışmaktan çok korktuklarını dile getirdiler. Ayrıca yüklerini çaldırmak, aracının soyulması, mazotlarının çalınması da korkularının içerisinde yer almaktadır.

SAD / JSR

Cilt / Volume 22 Sayı / Number 1 
“Bu işin en büyük korkusu kazadır. Sonra ne vardır... Hırsızlık var, özellikle belli yerlerde çok fazla. Mesela ben firmayı ararım yüküm boşalmayacaksa İstanbul'a girmem şehrin dışında bir parkta beklerim. Araçta uyurken yanmaktan da korkarım.” (Erkek, 32 yaşında, 4 yıldır yurt içi şoförlük yapıyor, 2500 TL, Kırşehir).

Araştırma boyunca en ilginç gelen yanıtlardan birisi akaryakıt yani mazot fiyatları üzerine olmuştur. Şoförler akaryakıt zamlarına direkt olarak karşı değildir. Onları asıl ilgilendiren zamların günlük olmasıdır. Günlük zam artışına karşın nakliye ücretlerinin aynı oranda artış göstermiyor oluşu şoförleri zor durumda bırakmaktadır. Bir şoförün deyişiyle;

“İstanbul'da pazarlığı yapıyoruz yükü alıyoruz. Bolu’da mazota zam gelmiş. Kazancımız daha yükü indirmeden erimeye başlıyor. Zamlar yıllık olsa ona göre nakliye ücretimizi hesaplarız kurtaracak mı biliriz.” (Erkek, 46 yaşında, 15 yıldır kendi aracında şoför, 3000-3500 TL arası, Nevşehir)

Şoförlerin üzerinde anlaştığı diğer bir konu ise Türkiye'de gereğinden çok ağır vasıta olduğu yönündedir. Ağır vasıtaların fazla olması, denetimsiz şekilde her parası olanın bu işe girebiliyor olması, mesleğin düzenli bir işleyişinin olmamasının en önemli nedeni olarak görülmektedir. Her dönem tır garajlarında satılmayı bekleyen onlarca tır olması bu durumun kanıtıdır. Üretim ilişkileri açısından bakıldığında ağır vasıta, sahibi için bir üretim aracıdır. Üretim aracının bu kadar çok sayıda ve farklı kişiler arası el değiştiren sektörlerin başında nakliye sektörü gelmektedir. Kişilerin yüz binlerce lira hatta bazen euro verilerek elde ettiği üretim aracı olarak ağır vasıtalar denetimsiz bir rekabet içerisinde çalışmaktadır. Günümüzde Türkiye Cumhuriyeti ulaştırma politikaları, izin ve vergi sistemini düzenlerken şahıs arabalarını değil, şirket veya filo firmalarının arabalarına göre düzenleme yapmaktadır. Bir veya iki ağır vasıtası olan şahıs arabaları bu politikalar karşısında giderek zor durumda kalmaktadır. İlerleyen yıllarda şirket veya filo bünyesinde çalışmayan, şahıslara ait ağır vasıtaları görmek giderek zorlaşacaktır.

SAD / JSR

Cilt / Volume 22 Sayı / Number 1 
" $\mathrm{Bu}$ iş giderek bitiyor. Arabası olan arabasını satıyor ya başka şirketin arabasını sürmeye başlıyor veya başka işe geçiyor. Ben bir araç için K belgesi alıyorum binlerce lira veriyorum. Şirket 10 araba çalıştırıyor yine tek K belgesi fiyatına." (Erkek 36 yaşında, 5 yıldır araç sahibi olarak şoför, 3000 TL ortalama, Adana).

Öte yandan bazı kamyonların arkasında yazan "özendiğiniz hayatı yaşamakla meşgulüm” veya bu perspektifte yazılan şoförlük mesleğini birçok kişinin yapmak istediği varsayılan cümlelerde yer alan özenme, istenme durumunun oluşmasının sebebi, iş yapıları gereği gündelik yaşam rutin işleyişine uygun olmayan çalışma biçimleridir. Örneğin bu özenti şehrin kalabalığından sıkılmış, aylardır hatta yıllardır şehirden ayrılamamış bir insanın şoförün tek başına ıssız bir ovada veya dağlar arasında manzaralar eşliğinde saatlerce gideceğini bildiğinden kaynaklanmaktadır. Gerçektende şoförler rutin iş yaşamında mesaisi biten insanlar dinlenmek ve uyumak için evine giderken tüm gece boyunca çalışmaya hazırlanırlar. Bir sonraki gün Türkiye'nin veya dünyanın neresine doğru yol alacakları belirsizdir. Şoförlerin hayatlarındaki bu belirsizlik aile, arkadaşlık, akraba ilişkilerini de belirlemektedir.

\subsection{Sorunlar ve Öneriler}

Uzun yol şoförleri ile yapılan bu araştırmada ortaklaşan sorunlar ve bu sorunlara ortaklaşan çözüm önerileri saptanmıştır. Bu başlık altında saptanın sorunları ve çözüm önerileri dört madde üzerinden anlatılmıştır.

1. Sorun: Komisyoncu, firma yetkilisi, şoför arasında belirlenen nakliye ücretinin standardı bulunmamaktadır. Aralarındaki iş ilişsisi denetimsizdir.

Çözüm Önerisi: Yapılan görüşmelerde yük ve uzaklık üzerinden belirlenmiş bir standart fiyat olmadığ1 saptanmıştır. Özellikle şirket araçları gittikleri ilden boş dönmek yerine çok daha ucuz nakliye ücretlerini kabul ederek araçlarını bağlı olduğu şehre veya fabrikaya geri getirtmektedir. Bu durum araç sahibi olarak şoförlerin en büyük sorunudur. Fiyat standardının sağlanması ve denetimlerin yapılması bu sorunun aşılması yönündeki en somut öneri olarak ortaya çımıştır.

SAD / JSR

Cilt / Volume 22 Sayı / Number 1 
2. Sorun: Mazot zamları.

Çözüm Önerisi: Uzun yol şoförleri, özellikle kendi aracına sahip uzun yol şoförleri akaryakıt zammına karşı değildir. Karşı oldukları şey zamların günlük, gecelik yapılmasıdır. Günlük zamlar nakliye ücretlerine yansıtılamadığı için kazançları kaybolmaktadır. Bu duruma somut öneri ise ticari yük taşımacılığı yapma yetki belgesi olan araçlara akaryakıt zamlarının günlük değil önceden tarihi belirli olan dönemlerde (3-612 ayda bir) gerçekleştirilmesidir."

3. Sorun: Trafik kurallarının ihlal edilmesi

Çözüm Önerisi: Trafikte kural ihlali yapıldığı zaman yalnızca ağır vasıta sürücüsüne ceza verilmemelidir. Aynı ceza belli bir oran saptanarak araç sahibine veya aracın bağlı bulunduğu şirkete vergi artışı olarak yansıtılmalıdır. Böylece şirket veya araç sahibinin uzun yol şoförü üzerinde kurduğu baskı (daha hızlı gel, daha fazla sefer at vb.) ile ortaya çıkan kural ihlallerinin önüne geçilebilecektir.

4. Sorun: İşini iyi yapan şoförün ödüllendirilmemesi

Çözüm Önerisi: Birçok sektörde olduğu gibi işini iyi yapan tecrübeli şoförler yerine tecrübesiz, düşük ücretle çalışacak şoförler piyasada belli firmalar ve şahıslar tarafından aranmaktadır. Bu durum tecrübeli ve işini iyi yapan şoförleri olumsuz etkilemekte, kimi zaman onları sektör değiştirmeye itmektedir. Bunun durdurulması ve yollarda tecrübeli, işini iyi yapan şoförlerin varlığının artması için kazaya sebep olmamış ve belli cezaları belirli sayıdan fazla almamış (kırmızı 1şık ihlali, takograf ihlali vb.) sürücülere erken emeklilik hakkı veya bu şoförleri çalıştıran firmalara vergi indirimi gibi haklar tanınmalıdır. 


\section{SONUÇ}

Çalışma boyunca ifade edilen ve belirtilen birçok bulgu ve yorumun ardından ortaya çıkmıştır ki, uzun yol şoförlüğünü anlatmak için en önemli kavram “sanı yaşamlar”dır. "Sanı” TDK (Türk Dil Kurumu) sözlüğünde sanma durumu veya sonucu olarak tanımlanmaktadır. Anlaşılmıştır ki, uzun yol şoförü yaşamları hep bir yerde olduğunu sanma ancak orda olmama, olamama, oraya bağlanmama, kalıcı olamama üzerine kurulmuştur. Birey sahip olduğu sosyal, kültürel, ekonomik sermaye stoklarını muhafaza ederek, güçlendirerek veya dönüştürerek, toplumsal hiyerarşi içerisindeki konumlarını korumakta veya yükseltmektedir (Swartz, 2011: 289). Ancak günümüzde "sanı yaşama” sahip şoför için bırakınız güçlendirme ve dönüştürmeyi sermaye stoklarını korumak ve muhafaza etmek dahi çok zordur. Bu nedenle uzun yol şoförlerinin toplumsal hiyerarşi içerisindeki konumları güçlü değildir. Konumlarının güçsüz olması, Türk toplumunun değer dünyalarının yapısı ve bu dünyalara ait değer ekonomilerinin işleyiş biçiminden kaynaklanmaktadır. Türk toplumunun en önemli değer dünyaları ailesel, yurttaşlık, piyasa, şöhret dünyaları olarak sıralanabilmektedir. Türkiye Cumhuriyeti vatandaşı her birey bu değer dünyalarına sahiptir. Ancak her bireyin sahip olma düzeyi ve gücü birbirinden farklıdır. Gündelik karşılaşmalarda bireyler bu değer dünyaları üzerinden birbiri ile ilişkiye girmekte ve birbirlerine karşı manevra yaparak hâkim mevzi elde etmeyi istemektedir. Bu konumlanmaları üzerinden değer ekonomisi oluşmaktadır. Değer ekonomilerinin işleyişi ise sosyal ilişkinin yapısını belirlemektedir. Bir birey tüm değer dünyalarına sahiptir. Ancak değer dünyalarının ekonomileri eşit değildir. Birey çok güçlü ailesel değer dünyası ekonomisine sahip iken güçsüz bir şöhret değer dünyası ekonomisine sahip olabilmektedir. Bireyler sahip oldukları en güçlü değer dünyası veya dünyaları üzerinden ilişki kurmayı seçmektedir. Örneğin babası üst düzey bir yönetici olan bir birey yaşadığı bir sorun esnasında ailesel değerinden elde ettiği gücü kullanarak "siz benim ailemin kim olduğunu biliyor musunuz? Lütfen gerekli yerleri aramadan işimi halledin" diyebilmektedir. Veya hiçbir kültürel sermayesi olmadığı halde son model bir arabayla ve güvenlik korumaları ile bir restorana gelen kişiye garsonların hemen en iyi masayı verme olgusu toplumun şöhret 
dünyası ekonomisini nasıl değerlendirdiğiyle ele alınmaktadır. Bu iki değer dünyası örneğinin ardından değer dünyalarının içeriğini tekrardan kısaca belirtmek gerekmektedir.

Ailesel dünya içerisinde bireyin ailesinden getirdiği nesil ayrımı, gelenek ve hiyerarşi önemlidir. Toplumda buradan gelen bilgilerin mantığına başvurularak hareket edilir. Bayramlarda, düğünlerde, doğum günlerinde, cenazelerde, akşam gezmelerinde kısacası iyi günde ve kötü günde aile üyelerinin yanında yer alabilmek ailesel dünya içerisinde değer ekonomisi sağlamada önemlidir. Şoförler ise genellikle böylesi günlerde yollarda, kendi tabirleriyle gurbette oldukları için ailesel dünya içerisinde gündüz çalışan akşam evinde olan veya sabit yaşayan bireye göre değerli bir ekonomiye sahip değildir, çalışma biçimleri nedeniyle ailesel değer ekonomilerini güçlendirme şansları zordur.

Piyasa dünyası ise bireyler arasındaki meta yarışına dayanır, bireyler zengin olduğu için değerli olarak görülmektedir. Şoförler ise yüz binlerce euro'luk tırı sürse, hatta sahibi bile olsa, yollarda yatıp kalkan, düzensiz yaşayan, zorluklarla dolu bir yaşama sahip bir insan olarak görüldüğü için piyasa dünyas1 içerisinde de değer ekonomileri düşüktür.

Şöhret dünyasındaysa “değer” insanların aklında ve fikirlerinde oluşturulamazsa hiçbir şey olduğu fikrine dayanmaktadır. İnsan değerinin ölçülebilirliği kamusal değer içerisindeki geleneksel işaretlere bağlıdır. Başarı ünle ve toplum içerisinde görünür olmayla ilgilidir (Boltanski ve Thévenot, 2006). Şoförlerin toplum içerisinde görünür olmayışı hatta yaptıkları işin herkesin kolaylıkla yapabileceği bir iş olarak sanılması şoförlerin şöhret dünyası içerisinde de değer ekonomilerinin güçsüz olmasını sağlamaktadır. Görüldüğü gibi Türk toplumunun önem verdiği ailesel, piyasa, şöhret dünyaları içerisinde şoförlerin değer ekonomileri ve sermaye biçimleri güçsüzdür. Şoförlük mesleğinin işleyiş yapısı, sabit mekânlarının ve ilişkilerinin olmayışı, toplumun geleneksel işleyiş zamanına ve geleneksel aile yapısına uygun çalışamıyor oluşları terimsel olarak ifade etmek gerekirse "sanı yaşamları" nedeniyle toplumsal hiyerarşi içerisinde değer ekonomilerinin ve sermayelerinin dönüşme, yükselme ihtimali oldukça düşüktür. Görüşmeler 
sırasında bir şoför bu durumu özetleyerek şöyle demiştir; "şoför ailesi, çocukları, uzaktaki sıcak yuvası için kendini düşünmeyen, hayatını onlar için bırakan insandır” (Erkek, 38 yaşında, 11 yıldır uluslararası şoförlük yapıyor, 4000 TL, Kırşehir) .

Türk toplum yapısının önemli değerleri olan ailesel, piyasa, şöhret dünyalarının değer ekonomileri içerisinde güçsüz olan uzun yol şoförleri Türk toplumunun bir diğer önemli değer dünyası olan yurttaşlık dünyasının değerleri içerisinde ise nispeten daha güçlü bir ekonomiye sahiptir.

Yurttaşlık dünyasında birey kendi değer ve ilgilerini bir kenara bırakarak toplumsal "ortak iyiye" doğru hareket eder. Ortak iyiyi belirleyen yasalar, haklar, refah devleti içerisinde yer alan dayanışma ve saygı prensipleridir (Boltanski ve Thévenot, 2006). Ve bu ortak iyiye doğru hareket etmede yani yurttaşlık dünyasının değer ekonomisini elde etmede ailesel, şöhret ve piyasa dünyasında olduğu gibi şoförlerin çalışma biçimi dezavantaj değildir. Ayrıca şoförlerin birçok meslek grubuna kıyasla ailesel, piyasa ve şöhret dünyalarının değer ekonomilerini güçlendirmekte zorlandıkları için bu değerleri bir kenara bırakarak yurttaşl1k dünyasında güçlü bir değer ekonomisi elde etme istekleri ve ortak iyiye doğru yönelmeleri daha kolaydır. Bu nedenle Türk toplumunun en önemli değer dünyaları ailesel, yurttaşlık, şöhret ve piyasa değer dünyaları içerisinde şoförlerin en güçlü oldukları değer ekonomisi yurttaşlık değer dünyasıdır. Bu durum toplumdaki algının ve sanılanın aksine, tüm inisiyatif şoförlere bırakıldığında (firmaların hızlı gel, fazla yükle vb. talepleri olmadığı durumlarda) şoförler kurallara uyan, yasalara, haklara, politika uygulayıcılarına (polis, jandarma vd.) saygı gösteren, haksızlıkları bilmelerine karşın devlet refahı adına 1lımlı davranan, şikayet etseler dahi belgelerini ve vergilerini ödemeye çalışan insanlara dönüştürmektedir. Çünkü uzun yol şoförleri Türk toplumunda gündelik ilişkileri belirleyen ailesel, yurttaşlık, piyasa ve şöhret değer dünyaları içerisinde yaşam biçimleri ve çalışma koşulları gereği diğer meslek grubu üyeleri ve insanlarla karşılaşmalarında en fazla yurttaşıاı dünyası değer ekonomileri içerisinde eşit veya güçlü olabilme şansına sahiptir. Ve yurttaşlık dünyasının değer ekonomileri gündelik yaşamlarını kolaylaştıran bir yapıya sahiptir. 
Özetle örnek ile anlatıldığında, bir öğretmen, bir kasiyer her gün akşam evini görmekte, her an ailesinin yanında olabilmektedir. Ancak bu durum uzun yol şoförü için aynı değildir. Ailesel dünya değeri üzerinden bakıldığında şoför ile öğretmen ve kasiyerin değeri ekonomisi aynı değildir. Şoförün ailesel dünya ekonomisi değeri daha güçsüzdür. Aynı şekilde, bir uluslararası tır şoförünün aylık geliri öğretmenden ve kasiyerden fazladır. Ancak piyasa dünyası değerleri içerisinde konumu daha kötü algılanmaktadır. Böylece piyasa dünyası değer ekonomileri içerisinde de öğretmen ve kasiyere göre daha kötü bir değer dünyası ekonomisine sahiptir. Şöhret dünyası içerisinde de öğretmene ve kasiyere göre eğitimsiz, kötü şartlarda çalışan değeri daha az olan kişi gibi görülmektedirler. Ancak şoförler bir tek yurttaşlık dünyası içerisinde diğer meslek grupları ile eşit değer ekonomisi geliştirme şartlarına sahiptir. Gündelik karşılaşmalarda diğer insanlar ve meslek grupları karşısında en güçlü manevra ve eyleme kapasiteleri yurttaşlık dünyası üzerinden olmaktadır. Yurttaşlık dünyasının ortak iyisine yönelik "Biz olmasak bu ekonomi dönmez, insanlar giyecek, yiyecek bir şey bulamaz, ihracat bizim sayemizde oluyor, bu ülkeye dövizi biz getiriyoruz, siz sıcak yatağınızda uyurken biz tüm gece kahvaltıda içeceğiniz çayı taşıyoruz" gibi söylemler yurttaşlık değerleri üzerinden kendi ayrıcalıklı konumlarını oluşturduklarının sözel ifadeleridir.

Özetle uzun yol şoförlerinin kendilerinden alınan veriler ışığında Pierre Bourdieu'nun sermaye biçimleri ve Luc Boltanski’nin değer dünyaları üzerinden şoförlerin değer ekonomilerinin ve sermaye yapısının işleyişi hakkında bilgi verildi. Böylece sosyolojik olarak bir uzun yol şoförünün yaşamının neden "sanı yaşamlar" ifadesi ile açıklanabileceği anlatıldı. Sanı yaşamların etkisinden kurtulmak, gündelik yaşamda daha güçlü manevra ve ilişki yapıları kurabilmek için yurttaşlık dünyasının değerleri ile kurulan ilişkinin nedenleri ve biçimi açıklandı. Son olarak belirtilmelidir ki; uzun yol şoförlerinin (değer dünyalarının birçoğunda) kaybetmişlik hissi ve bu histen kaçmak için işlerini, yaptıkları işi ve araçlarını yüceltmesüsleme durumu, en fazla yurttaşlık dünyası içerisinde diğer insanlarla eşit değer ekonomileriyle rekabet edebileceklerini bilmeleri hayata, topluma dair söylemlerinin yapısını belirlemektedir. Şoförlerin çalışma biçimi ve koşulları ile Türk toplumunun değerler ekonomisinin yapısının uyumsuz olması (Yurttaşlık değer 
dünyası dışında) nedeniyle şoförler toplumsal hiyerarşide düşük konumdadır. Ve bu işten ayrılmak isteseler dahi, değer dünyalarının güçsüzlüğü ile yüzleşmek yerine, "sanı yaşama" devam etmeyi tercih etmektedirler. Bu durum bir şoförün deyimiyle "bu iş hastalık, bırakmak istesen de bırakamıyorsun. Ben bıraktım altı ay sonra geri geldim” şeklinde özetlenmiştir. 


\section{SUMMARY}

This research is carried out through qualitative research method in the case of long distance drivers in Turkey. In-depth interviews were conducted with fifteen long distance drivers in the cities of Adana, Niğde, Nevşehir and Mersin. The network of long distance drivers has been outlined as inthey should contact with vehicle owner, company employee, middleman and other long distance drivers. Their ideas about speed, fear, hope, food, distance have been revealed. Fear is in relation with traffic accident, hope is in relation with pension, speed is in relation with achievement of the task. Their main problem is the lack of inspection on shipping charge. Second problem is petrol price rises. Their suggeston is that rises in petrol price should be periodical not random or surprise. Thirdly,they would prefer if the traffic fines were not onlypaid by the long distance drivers but also vehicle and company ownersin the way of tax fines so that anyone could not compel drivers to fast delivery.

The study showed that the most important concept to describe the long-distance driver is the"Assumption Life" as thedriver is actually at nowhere when he/she is also everywhere because of the working time and the location. Home, factory, workplace and so on, everyplace is ephemerae for the long-distance driver. However, the most essential value worlds of the Turkish society which is family, market and fame worlds, require permanent space and relationship network. Every people has all the value worlds into some extent but the economies of them are not equal. Individuals are connected with each other through these value worlds in everyday life. Individuals prefer to move within the world of value they feel strong. In the family world, being with the family is important for the position in the social hierarchy.In the world of fame, success depends on the fame and being visible in a good manner in the society. The market world is based on the meta-race between individuals who are seen as valuable if they are rich. Drivers' life is not suitable with the value of fame, family, and market world so that they cannot provide strong value in these worlds to rise in the social hierarchy. Yet drivers have opportunity to have a strong value economy with in the civic value world, another important value world of Turkish society. Its common goodsare the principles of 
solidarity and respect to laws, rights, law-enforcement officers, bureaucratic institutions, and social order.

For this reason, drivers are motivated to move towards the"commongood", which determines the value of the civic world. 


\section{KAYNAKÇA}

Başkale, H. (2016). Nitel Araştırmalarda Geçerlik, Güvenirlik ve Örneklem Büyüklügü. Dokuz Eylül Üniversitesi Hemşirelik Fakültesi Elektronik Dergisi, 23-28. Erişim Adresi: http://www.deuhyoedergi.org/index.php/DEUHYOED/article/download/207/221

Boltanski, L., ve Thêvenot, L. (2006). On Justification: Economies of Worth. New Jersey: Princeton University Press.

Bourdieu, P., ve Wacquant, L. (2003). Düşünümsel Bir Antropoloji İçin Cevaplar. İstanbul : İletişim Yayınlar1.

Göker, E. (2007). Ekonomik İndirgemeci mi Deniniz? G. Çeğin, E. Göker, A. Arlı, \& Ü. Tatlıcan (Ed.) Ocak ve Zanaat: Pierre Bourdieu Derlemesi içinde (s. 277-303). İstabul: İletişim Yayınları.

Hammersley, M., ve Atkinson, P. (2007). Ethnography Principles in Practice. New York: Routledge.

Jacquemain, M. (2008). Boltanski's Moral Sociology and His Implicit Theory of Ideology. ErişimAdresi: https://orbi.ulg.ac.be/bitstream/2268/90314/1/Boltanski's\%20moral\%20sociology\%20and\%20his \%20implicit\%20theory\%20of\%20ideology.pdf (Erişim Tarihi: 10.01.2018)

Öztürk, O. (2013). Türkiye'de Trafik Kazaları Gerçeği II . İstanbul: Pasifik Ofset.

Resmi Gazete (2016). Demiryolu Eğitim ve Sinav Merkezi Yönetmeliği. Say1: 29935 Erişim Adresi: http://www.resmigazete.gov.tr/eskiler/2016/12/20161231-6.htm (Erişim Tarihi: 14.01.2018)

Resmi Gazete (2015). Karayolları Trafik Yönetmeliğinde Değişiklik Yapılmasına Dair Yönetmelik. Sayı:29329. Erişim Adresi: http://www.resmigazete.gov.tr/eskiler/2015/04/20150417-3.htm (Erişim Tarihi: 14.01.2018)

Resmi Gazete (2009). Karayolu Taşıma Yönetmeliğinde Değişiklik. Sayı: 27255. Erişim Adresi: http://www.resmigazete.gov.tr/eskiler/2009/06/20090611-2.htm (Erişim Tarihi: 15.01.2018)

Shaffer, B. (2009). Boundaries of Order Private Property As a Social System. Alabama: Ludwig von Mises Institute.

Swartz, D. (2011). Kültür ve İktidar Pierre Bourdieu'nun Sosyolojisi. İstanbul: İletişim Yayınları.

SAD / JSR

Cilt / Volume 22 Sayı / Number 1 
TUIK (2017). Karayolu Trafik Kaza İstatistikleri - 2016. Kaynak:

http://www.tuik.gov.tr/PreHaberBultenleri.do?id=24606 Erişim Tarihi: 16.01.2018.

Uslu, A. (2017). Yeni Ümit Eğitim Kurumları. Retrieved Kasım 19, 2017, from scrbelgesi İstanbul: http://www.srcbelgesiistanbul.com (Erişim Tarihi: 05.02.2018)

Yıldırım, A., Şimşek, H. (2013). Sosyal Bilimlerde Nitel Araştırma Yöntemleri. Ankara: Seçkin Yayıncılık. 